\title{
Phytochemistry and pharmacological profile of traditionally used medicinal plant Hyssop (Hyssopus officinalis L.)
}

Mohd Tahir, Mohammad Khushtar, Mohd Fahad, Md. Azizur Rahman*

Department of Pharmacy, Integral University, Lucknow, Uttar Pradesh 226026, India.

\begin{tabular}{|c|c|}
\hline ARTICLE INFO & ABSTRACT \\
\hline $\begin{array}{l}\text { Article history: } \\
\text { Received on: } 14 / 04 / 2018 \\
\text { Accepted on: } 28 / 05 / 2018 \\
\text { Available online: } 30 / 07 / 2018\end{array}$ & $\begin{array}{l}\text { Several research publications are published on the medicinal plant Hyssopus officinalis L. But, the researchers find } \\
\text { quite a difficulty to study all the publications in a short while. The present review was designed to compile and } \\
\text { summarize all the published works on the medicinal plant } H \text {. officinalis L. traditionally used in several systems of } \\
\text { medicine (1885-2018). It showed that the medicinal plant } H \text {. officinalis L. belonging to family Lamiaceae, is a very } \\
\text { important culinary, medicinal and perennial plant wildly cultivated in Asia, Europe and America. It possesses numerous }\end{array}$ \\
\hline $\begin{array}{l}\text { Key words: } \\
\text { Hyssop, Hyssopus } \\
\text { officinalis, Pharmacology, } \\
\text { Phytochemistry, Traditional } \\
\text { uses. }\end{array}$ & $\begin{array}{l}\text { phytoconstituents including quercetin-7-O- } \beta \text {-D-apiofuranosyl- }(1 \rightarrow 2)-\beta-\mathrm{D} \text {-xylopyranoside and quercetin-7-O- } \beta-\mathrm{D}- \\
\text { apiofuranosyl- }(1 \rightarrow 2)-\beta \text { - } \mathrm{D} \text {-xylopyranoside-3'-O- } \beta \text {-D-glucopyranoside and possesses antioxidant, anticonvulsant, } \\
\text { antifungal, antimicrobial, antihemolytic, antiulcer, antispasmodic and several other pharmacological activities. Its } \\
\text { essential oil is widely being used in cosmetic, food and pharmaceutical industries worldwide. Its oil is used as an } \\
\text { herbal medicine and very precious food additive. It is one main ingredient of the official formulation of Chartreuse. } \\
\text { Za'atar is its well-known herbal formulation. It is a quite significant medicinal plant which can be utilized for the } \\
\text { treatment of several diseases such as microbial infection, epilepsy, ulcer, and spasm. }\end{array}$ \\
\hline
\end{tabular}

\section{INTRODUCTION}

The medicinal plant Hyssopus officinalis L., commonly known as Hyssop (in English), Jufa (in Sanskrit), Zufah-yabis (in Hindi), Zufah (in Urdu) and belonging to family Lamiaceae, is a very important culinary, medicinal and perennial plant wildly cultivated in Asia, Europe and temperate regions of America (Fathiazad et al., 2011). It is largely distributed in Central Asia to East Mediterranean. Generally, the health benefits and therapeutic uses of $H$. Officinalis are generally based on tradition rather than on any scientific validation, thus, making it an excellent candidate to assemble data, including phytochemical contents, traditional uses and biological activities accessible in recent scientific studies (Fathiazad et al., 2011). Recently the biocidal (nematicidal, ixodicidal, phytotoxic and insecticidal) effects of industrial steam distilled essential oil from $H$. officinalis shown that it was effective and robustly active against $S$. littoralis (Ortiz de Elguea-

${ }^{*}$ Corresponding Author

Md. Azizur Rahman, Department of Pharmacy, Integral University,

Lucknow, Uttar Pradesh 226026, India.

E-mail:marahman@gmail.com
Culebras et al., 2018). H. officinalis essential oil also showed it as eco-friendly, effective and cheap mosquito larvicidal agent (Benelli et al., 2017). H. officinalis L. affects numerous cytokines in mice with induced asthma including interleukin4 (IL-4), IL6 and IL17 and interferon $\gamma$. H. officinalis is an oil-rich plant which is native to the Caucasus, Turkish North Eastern Black Sea region, North Western Iran and Southern Anatolia which is an extremely esteemed medicinal plant (Kizil et al., 2008).

Hyssopus officinalis stimulates digestion and acts as antiseptic. The plant was in a vegetative phase in the month of mid-June, the start of flowering in mid-July, full blooming in mid of August and after flowering in mid of September. The effect of plant harvesting and plant spacing $(30 \times 30,40 \times 40,50 \times 50 \mathrm{~cm})$ upon the quantity and yield of $H$. officinalis herb was evaluated in the year from 2006 to 2008. Considerably, larger plant yield was found from the plant after flowering, just like the dry yield of the plant without stems. It was also revealed during this study that the highest fresh plant yield of $1.47 \mathrm{~kg} / \mathrm{m}^{2}$ was from plant grown in $40 \times 40 \mathrm{~cm}$ spacing, similarly to the dry yield of the plant without stems. The contents of oil, dry matter, chlorophyll, $l$-ascorbic acid, flavonoids, carotenoids, and tannins were not significantly 
affected by the plant spacing. However, the contents of $l$-ascorbic acid, essential oil, chlorophyll and carotenoids in H. officinalis herb were significantly affected by the harvest term (Zawislak, 2011).

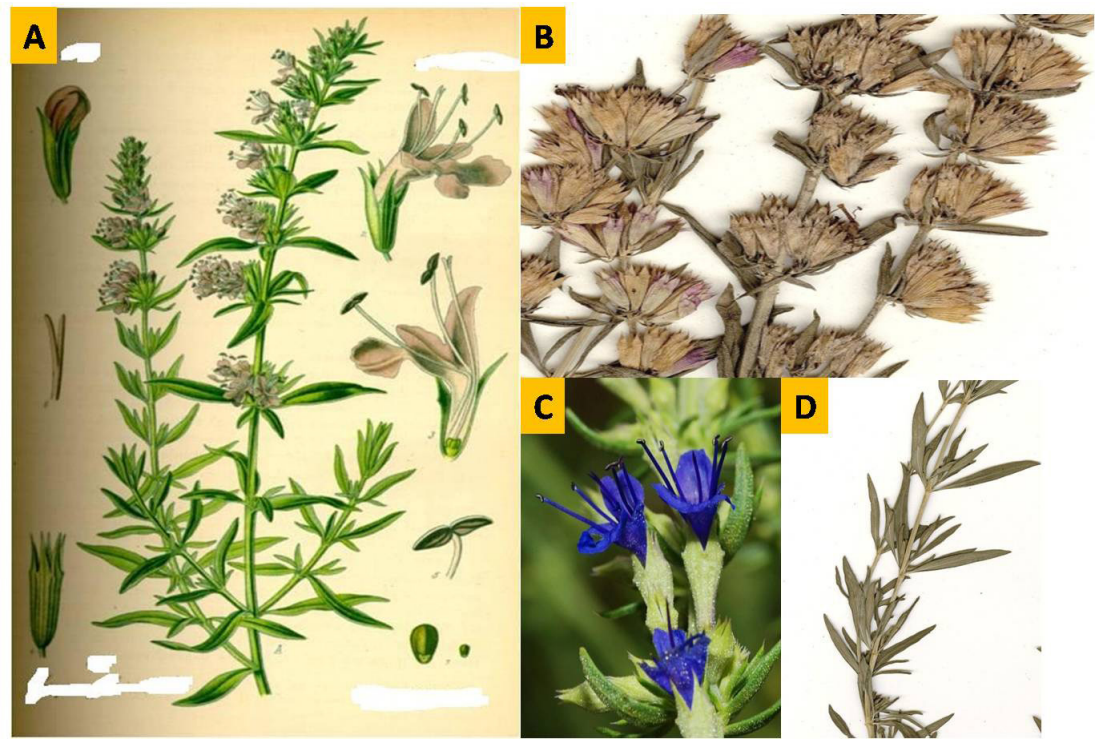

Fig. 1: Images of the plant Hyssopus officinalis L. and its parts: [A]. A twig from the whole plant of H. officinalis, [B]. Fruits, [C]. Flowers, and [D]. Leaves (Thome, 1885).

The moderate temperature for proper germination of $H$. officinalis was established to be at $20^{\circ} \mathrm{C}-30^{\circ} \mathrm{C}$. The maximum germination rate was obtained at $30^{\circ} \mathrm{C}$. So, the warmer temperature is very suitable for it. The optimum seedlings growth was established to be at $30^{\circ} \mathrm{C}$ (Mijani et al., 2013). Application of biofertilizers Pseudomonas fluorescens/Bacillus subtilis/ Azospirillum (Super Nitro Plus); Azotobacter/Azospirillum (Nitroxin), Glomus intraradices (Mycorrhizal inoculant) and Pseudomonas fluorescens enhanced the yield and other plant criteria of $H$. officinalis. $H$. officinalis had shown better plant criteria with the proper application of a mixture of Glomus intraradices and Pseudomonas fluorescens; and Super Nitro Plus (Tabrizi et al., 2008). Images of the plant Hyssopus officinalis L. and its parts are shown in Figure 1.

\section{TRADITIONAL USES}

The plant $H$. officinalis has been used traditionally for medicinal purposes (Fathiazad et al., 2011). Its essential oil is widely being used in cosmetic, food and pharmaceutical industries worldwide. In herbal systems of medicine, $H$. officinalis is supposed to possess soothing, expectorant, and cough suppressant properties. It can stimulate the gastrointestinal system. It is being used in formulations of sauce and also as an ingredient of food in flavor industry (Kazazi et al., 2007). Its oil is used as an herbal medicine and very precious food additive. It is moderately used for food preparation. Fresh herb of $H$. officinalis is usually used in cooking (Fernández-López et al., 2003). Za'atar is a wellknown herbal mix of Middle East where dried leaves of $H$. officinalis is used as the main ingredient. The essence of $H$. officinalis is used in food preparation to a minor extent. $H$. officinalis is used to flavor liqueur and is one main ingredient of the official formulation of Chartreuse (Kazazi et al., 2007). It is generally used by beekeepers to produce an aromatic and rich honey. Its leaves are used as an aromatic condiment and have a slightly bitter taste due to its tannins and an intense minty aroma (Paun et al., 2014).

\section{PHYTOCHEMISTRY}

Total flavonoids and phenolic contents found to be highest in $H$. officinalis L. ssp. angustifolius leaves aqueous extracts were $1.3 \%$ (gallic acid equivalent) and $4.7 \%$ respectively (Hatipoglua et al., 2013). Proanthocyanidine was present in a very high concentration in aqueous, chloroform and hexane extracts of the leaves, predominantly in chloroform extract of the leaves $(10250 \mathrm{mg} / \mathrm{L})$ (Hatipoglua et al., 2013). HPLC analysis validated the occurrence of antioxidant phenolics such as caffeic acid $(111.09 \mathrm{~g} / \mathrm{g})$ and chlorogenic acid $(166.21 \mathrm{~g} / \mathrm{g})$ in methanolic extract of the leaves (Hatipoglua et al., 2013).

Total phenol content in the $n$-butanol and ethylacetate extracts of the aerial parts was found to be $246 \mathrm{mg}$ gallic acid equivalent (GAE)/g and $51 \mathrm{mg} \mathrm{GAE} / \mathrm{g}$. The major flavonoid apigenin-7-O- $\beta$-D-glucuronide was isolated from the hydromethanolic extract of aerial parts. The other main compounds isolated were myrtenyl acetate, camphor, germacrene and spathulenol (Fathiazad et al., 2011).

Main constituents in $H$. officinalis extract from root removed whole plant in various supercritical fluid conditions of extraction were sabinene $(4.2 \%-17.1 \% \mathrm{w} / \mathrm{w})$, iso-pinocamphene $(0.9 \%-16.5 \%)$ and pinocamphene (0.7\%-13.6\%) (Kazazi et al., 2007).

The main constituents in $H$. officinalis were some polyphenolic compounds principally including flavonoids luteolin, diosmin, quercetin, apigenin and their glucosides along with some phenolic acids such as caffeic acids p-hydroxybenzoic, syringic, ferulic, protocatechuic and chlorogenic acid. Essential oils from $H$. officinalis aerial parts had shown some principal constituents such as terpenoids $\boldsymbol{\beta}$-pinene, isopinocamphone and pinocamphone (Fathiazad et al., 2011). 

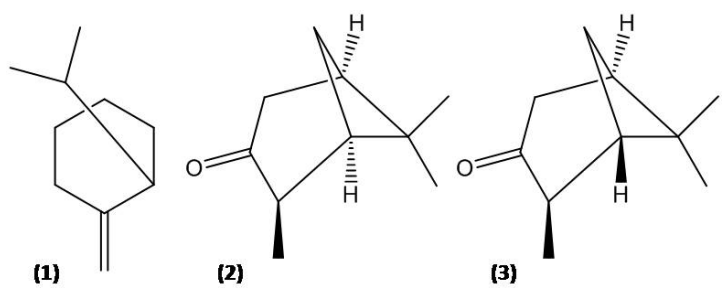

(3)<smiles>C=C1CCC2CC1C2(C)C</smiles>

(4)<smiles>CC12CCC(CC1=O)C2(C)C</smiles>

(5)<smiles>C=C1C=CC(C(C)C)CC1</smiles>

(6)<smiles>C=C(/C=C\C(CC/C(C)=C\C)C(C)C)CC/C=C\C</smiles><smiles>CC1(C)C2CC=C(CO)C1C2</smiles><smiles>CCCCCC(O)CC</smiles>

(8)

(9)<smiles>C=CC(C)(O)CCC=C(C)C</smiles>

(11)<smiles>OCc1ccccc1</smiles>

(12)<smiles>OCCc1ccccc1</smiles>

(13)<smiles>C=CCc1ccc(O)c(OC)c1</smiles>

(14)<smiles>COc1cccc(C=O)c1O</smiles><smiles>O=C1O[C@H]([C@@H](O)CO)C(O)=C1O</smiles>

(16)<smiles>CC1=CCC(O)(C(C)C)CC1</smiles><smiles>C=C1C(=O)CC2CC1C2(C)C</smiles><smiles>C=CC(C)(CCC=C(C)C)OC(C)=O</smiles><smiles>C/C=C(\C)OC1OCC2OC(O)C(O2)C1OC1OCC2OC1C2O</smiles>

(17)

(19)

(20)<smiles>C=CC(=C)c1oc2cccc(O)c2c(=O)c1O</smiles><smiles>CC1OCC(O)C(O)C2OC3OC(O)C(O)C(O3)C1O2</smiles><smiles>O=c1c(O)c(-c2ccc(O)c(OC3OC(CO)C(O)C(O)C3O)c2)oc2cccc(O)c12</smiles>

(21)

Fig. 2: Phytoconstituents reported in $\boldsymbol{H}$. officinalis: Sabinene (1), iso-pinocamphene (2), pinocamphene (3), $\beta$-pinene (4), Camphor (5), $\alpha, \beta$-phellandrene (6), germacrene D (7), Myrtenol (8), octan-3-ol (9), Linalool (10), cis-nerolidol (11), benzyl alcohol (12), Phenylethanol (13), Eugenol (14), $o$-vanillin (15), $l$-ascorbic acid (16), terpinen-4-ol (17), Pinocarvone (18), Linalyl acetate (19), quercetin-7-O- $\beta$-D-apiofuranosyl-( $\rightarrow 2)-\beta$-D-xylopyranoside (20), quercetin 7-O- $\beta$-D-apiofuranosyl$(1 \rightarrow 2)-\beta$-D-xylopyranoside-3'-O- $\beta$-D-glucopyranoside (21).

Yields of essential oil hydrodistilled from above ground portions of $H$. officinalis raised via seeds were $1.18 \%$ on dry herbage weight basis and $0.25 \%$ on fresh herbage weight basis. The essential oil (95.6\%) had shown the presence of six sesquiterpene hydrocarbons $(0.35 \%)$, one phenol $(0.2 \%)$, five oxygenated monoterpenes $(60.5 \%)$ and seven monoterpene hydrocarbons $(32.3 \%)$ in gas chromatographic and mass spectrometry (GCMS) analysis. The major constituents of the camphor odor oil were pinocamphone $(49.1 \%), \beta$-pinene $(18.4 \%)$, isopinocamphone (9.7\%) (Garg et al., 1999).

The $\beta$-pinene, camphor, pinocamphone plus 15 other terpenes were present in essential oils at three stages of development in GCMS analysis, among which were myrtenol derivatives, germacrene $\mathrm{D}, \alpha$-phellandrene and $\beta$-phellandrene 
and isopinocamphone. It showed the occurrence of glycosidically bound volatiles also in low concentration $(0.01 \%-0.06 \%)$ such as bicyclic terpenes verbenol and myrtenol in leaves (Schulz and Stahl-Biskup, 1991).

Aqueous methanolic extract of leaves of dried $H$. officinalis showed an $\alpha$-glucosidase inhibitory activity and also showed (7S,8S)-syringoylglycerol-9-O-(6'-O-cinnamoyl)- $\beta$ D-glucopyranoside and (7S,8S)-syringoylglycerol-9-O- $\beta$-Dglucopyranoside as evident from spectroscopic data of isolated compounds (Matsuura et al., 2004).

The essential oil steam distilled from $H$. officinalis showed $\beta$-pinene $(16 \%)$ and 1,8 -cineole $(53 \%)$ as the major constituents in GCMS analysis (Ortiz de Elguea-Culebras et al., 2018).

The essential oil from the herb of $H$. officinalis showed 31 compounds in steam distilled oil, 36 compounds in hydrodistilled oil and 27 compounds in hydrodistilled oil by DeanStark apparatus in GCMS analysis. All the analyzed oil samples showed the presence of isopinocamphone as the main constituent (40.07\%-45.45\%) (Wesolowska et al., 2010).

The primary active compounds in oil of $H$. officinalis were cis-3-pinanones and trans-3-pinanones (Hold et al., 2002).

The H. officinalis essential oil showed saturated bicyclic monoterpene ketones isopinocamphone and pinocamphone with few myrtenol derivatives (Karp and Croteau, 1992).

There is a high capability to save water through longer irrigation intervals of $H$. officinalis (e.g. 14 days) in Khorasan's semi-arid conditions as the crop serves as an alternative income source in the years of dry conditions (Khazaiea et al., 2008).

Stage of blooming and environmental conditions seriously affect the oil contents in H. officinalis with the highest oil contents and yield at the post-blooming stage. Isopinocamphone was found to the primary component (47.9\%-51.4\%) amongst the twenty-nine components in the analyzed $H$. officinalis essential oil analyzed by GCMS analysis (Kizil et al., 2008).

The major compounds shown in essential oil from supercritical extracts of $H$. officinalis were terpinen-4-ol $(5 \%)$, 1,8-cineol (75\%), $\beta$-pinocarvone (4\%) and pinene (4\%) along with some heavier compounds (Langa et al., 2009).

Dimethyl sulfoxide (DMSO) extracts of $H$. officinalis leaves showed two main phenolics in high-performance liquid chromatography (HPLC) analysis along with diosmin and isoferulyl-D-glucose ester as the major constituents (Mario et al., 1998).

The essential oil of Spanish $H$. officinalis showed elevated contents of $\beta$-pinene (16.82\%) and 1,8-cineole (52.89\%) as the main constituents in gas chromatography (GC) analysis (Vallejo et al., 1995).

The volatile components in four H. officinalis phenotypes differentiated by the color of their corolla showed three ketones pinocarvone, isopinocamphone and pinocamphone as the chief components which can be used to differentiate these phenotypes. The phenotype with the blue flower was more intense in odor than the other phenotypes (Kerrola et al., 1994).

The new flavonoid glycosides namely quercetin-7-O- $\beta$-D-apiofuranosyl- $(1 \rightarrow 2)-\beta$-D-xylopyranoside-3'-O- $\beta$-D-glucopyranoside and quercetin-7-O- $\beta$-D-apiofuranosyl- $(1 \rightarrow 2)-\beta$-D-xylopyranoside were isolated from the whole herbs of H. officinalis cultivated in Xinjiang Uygur Autonomous Region of China (Wang and Yang, 2010).

Isopinocamphone and pinocamphone $(43.3 \%$ and $4.4 \%$ respectively) were present in $H$. officinalis according to the ISO 9841 Standard (1991 E) but they were lacking in var. decumbens where limonene $(5.1 \%), 1,8$-cineole $(12.3 \%)$ and linalol $(51.7 \%)$ instead were predominantly present (Mazzanti et al., 1998a).

GCMS analysis showed that $\beta$-pinene $(10.8 \%$ and $10.5 \%)$, isopinocamphone $(29 \%$ and $3.2 \%$ ) and pinocamphone $(18.5 \%$ and $34 \%)$ were the major constituents in the two essential oils of plant $H$. officinalis which were grown in different areas near Urbino (Italy, Marche) (Fraternale et al., 2004).

GCMS analysis showed that the myrtenal (2.32\%), p-cymene $(2.81 \%)$, carvacrol $(3.02 \%)$, pinocarvone $(6.49 \%)$, (-)-terpinen-4-ol (7.13\%), (-)- $\beta$-pinene $\quad(7.23 \%) \quad$ and isopinocamphone $(57.27 \%)$ were present as the major constituents in the hydrodistilled essential oil of $H$. officinalis leaves which were collected in the Turkey Southeast Anatolian from wild (Kizil et al., 2010).

High-performance liquid chromatography and mass spectrometry (HPLC-MS) analysis showed free flavonoid aglycons (quercetin, luteolin), flavonoid glycosides (quercitrin, isoquercitrin and rutin) and phenolic acid derivatives (ferulic, chlorogenic, $p$-coumaric, caffeic, gentisic and caftaric acids) in dissimilar concentrations in $H$. officinalis ethanolic extract along with large amount $(77.72 \mathrm{mg} / \mathrm{g})$ of the polyphenolic compounds (Vlase et al., 2014).

The yield of hydrodistilled essential oil in stem, flower, and leaf of $H$. officinalis collected from Western-Himalaya (Chamoli, Uttarakhand, India) varied from $0.22 \%$ to $4.4 \%$. Fifty-seven constituents (88.4\%) of the stem oil, 44 constituents $(99.4 \%)$ of the flower oil and 57 constituents $(99.8 \%)$ of the leaf oil were identified in it. Major components of the oils were transpinocamphone $(<0.05 \%-1.3 \%)$, myrcene $(0.5 \%-1.3 \%)$, myrtenol $(1.4 \%-1.7 \%)$, isopimara-9(11), 15 -diene $\quad(<0.05 \%-1.9 \%)$, sabinene $(0.8 \%-1.9 \%), \beta$-phellandrene $(1.8 \%-3.2 \%)$, myrtenyl methyl ether $(2.7 \%-3.0 \%), 1,8$-cineole $(2.9 \%-8.0 \%), \beta$-pinene $(5.7 \%-9.3 \%)$, pinocarvone $(5.5 \%-24.9 \%)$ and cis-pinocamphone $(49.7 \%-57.7 \%)$. The leaf and stem oil were relatively similar in terms of pinocarvone and cis-pinocamphone content. The flower oil was differentiable from the leaf and stem oils due to the presence of a higher quantity of pinocarvone (Pandey et al., 2014).

Steam distilled oil from fresh aerial parts of three Italian $H$. officinalis strains wildly grown in diverse natural habitats of the Abruzzi region (Central Italy) shown thirty-three compounds in it. One of the strains shown very high content of limonene (15.9\%) and methyl eugenol (43.9\%), another contained 1,8-cineole $(23.1 \%)$ and $\beta$-pinene $(24.7 \%)$ as main components, while the third one was with high contents of $\beta$-pinene $(19.3 \%)$ and myrtenol (32.6\%) (Piccaglia et al., 1999).

$H$. officinalis essential oil content was ranged from $0.13 \%$ to $0.26 \%$ and the content improved with time. The yield of $H$. officinalis essential oil ranged from $7.3 \mathrm{~kg} / \mathrm{ha}$ to $19.6 \mathrm{~kg} /$ ha. The major components were $\beta$-pinene $(5 \%-15 \%)$ and isopinocamphene plus pinocamphene (57\%-75\%). Delayed harvest improved myrcene, $\beta$-pinene, and limonene plus cineole concentrations but reduced isopinocamphone plus pinocamphone. The chemical composition of $H$. officinalis oil from Mississippi 
was same as commercial oils from US, France, Canada and Bulgaria (Zheljazkov et al., 2012).

The essential oils from $H$. oflicinalis L. ssp. aristatus (Godr.) Briq. Wild at two stages of development were same in composition with 1,8-cineole (48.2\% and $39.6 \%)$, isopinocarnphone (16.3\% and $29.2 \%)$ and $\beta$-pinene $(11.4 \%$ and $39.6 \%$ ) as major components. However, the commercial essential oil from $H$. officinalis contains larger amounts of $\beta$-pinene (14.2\%), pinocamphone (10.3\%) and isopinocamphone $(40.2 \%)$ (Tsankova et al., 1993). The main phytoconstituents reported in H. officinalis L. are shown in Figure 2.

\section{PHARMACOLOGICAL ACTIVITIES}

\section{Antioxidant activity}

Two novel flavonoid glycosides quercetin-7$\mathrm{O}-\beta$-D-apiofuranosyl- $(1 \rightarrow 2)-\beta$-D-xylopyranoside and quercetin-7-O- $\beta$-D-apiofuranosyl- $(1 \rightarrow 2)-\beta$-D-xylopyranoside-3'$\mathrm{O}-\beta$-D-glucopyranoside isolated from $H$. officinalis performed the potent scavenging of stable 2,2-diphenyl-1-picrylhydrazyl radical (DPPH) (Wang and Yang, 2010).

H. officinalis var. angustifolius stems, leaves, and flowers ethanolic extracts showed moderate iron (II) chelating ability, good scavenging hydrogen peroxide, good antioxidant activity in the hemoglobin-induced linoleic acid model and good antioxidant activity in a concentration-dependent manner. Inhibitory concentration fifty percent $\left(\mathrm{IC}_{50}\right)$ for DPPH scavenging were found to be $148.8 \pm 4.31 \mu \mathrm{g} / \mathrm{ml}$ for flowers, $208.2 \pm 6.45 \mu \mathrm{g} /$ $\mathrm{ml}$ for leaves and $79.9 \pm 2.63 \mu \mathrm{g} / \mathrm{ml}$ for stems (Alinezhad et al., 2013).

H. officinalis extract blended in pork meat samples was seen to inhibit degradation of heme pigments and lipid oxidation caused by cooking and storage for 8 days at $4^{\circ} \mathrm{C}$. It also stabilized the red meat color and delayed metmyoglobin formation during cooked meat storage (Fernández-López et al., 2003).

Aqueous extract showed better DPPH radical scavenging activity as compared to chloroform and hexane automated extracts of $H$. officinalis var angustifolius leaves and water distilled Clevenger derived essential oil. The $\mathrm{IC}_{50}$ values of the chloroform extract, water extract and methanol-water (1:1) macerated extract were $28.80,18.80$ and $250 \mu \mathrm{g} / \mathrm{ml}$, respectively. The nonpolar extract was more active in $\beta$-carotene/linoleic acid test system (Hatipoglua et al., 2013).

The antioxidant activity of $H$. officinalis essential oil from Turkey Southeast Anatolian for scavenging of DPPH radical was lower as compared to the standards butylated hydroxytoluene (BHT) and ascorbic acid (Kizil et al., 2010).

$H$. officinalis ethanolic extract showed a good antioxidant activity as witnessed by Trolox equivalent antioxidant capacity assay, electron paramagnetic resonance radical detection assay, DPPH radical scavenging assay and hemoglobin ascorbate peroxidase activity inhibition assay (Vlase et al., 2014).

The purified flavonoid (apigenin-7- $O-\beta$-D-glucuronide) from $H$. officinalis showed weak scavenging of DPPH radical $\left(\mathrm{IC}_{50}=116 \times 10^{-3} \mathrm{mg} / \mathrm{ml}\right)$. The $n$-butanol extract, because of the highest content of total phenolics (246 mg GAE/100g) had the best scavenging of DPPH radical $\left(\mathrm{IC}_{50}=25 \times 10^{-3} \mathrm{mg} / \mathrm{ml}\right.$ ) while ethylacetate extract, the $\mathrm{IC}_{50}$ value of $103 \times 10^{-3} \mathrm{mg} / \mathrm{ml}($ Fathiazad et al., 2011). H. officinalis essential oil did not modify the ruminal fermentation. Antioxidant activity was found to be $2039 \mu \mathrm{mol}$ Trolox equivalent per liter (TE/L) (Zheljazkov et al., 2012).

\section{Anticonvulsant activity}

Trans-3-pinanones, cis-3-pinanones and $H$. officinalis oil acted as $\mathrm{GABA}_{\mathrm{A}}$ receptor antagonists based on inhibition of 40-ethynyl-4- $n-\left[2,3-3 \mathrm{H}_{2}\right]$ propylbicycloorthobenzoate $([3 \mathrm{H}]$ EBOB) binding in brain membranes of mouse $\left(\mathrm{IC}_{50}\right.$ : 35-64 $\mathrm{mM}$ ) and well supported by mouse tonic/clonic convulsions (intraperitoneal (i.p.) lethal dose fifty percent $\left(\mathrm{LD}_{50}\right) 175 \mathrm{mg} / \mathrm{kg}$ to $>250 \mathrm{mg} / \mathrm{kg}$ ) alleviated by diazepam. 2-Hydroxy-cis-3-pinanone and 2,10-dehydro-3-pinanone, the cis-3-pinanone metabolites exhibited reduced toxicity and potency for inhibition of $[3 \mathrm{H}]$ EBOB binding (Hold et al., 2002).

\section{Antifungal activity}

H. officinalis oil $(0.4 \%)$ entirely inhibited the mycelium growth of Pyricularia oryzae and Pyrenophora avenae, the plant pathogenic fungi, in vitro in agar medium. Pinocamphone, isopinocampheol and $l$-bornyl acetate, the components of $H$. officinalis oil, completely inhibited fungal growth individually and, also in combinations when mixture contained isopinocampheol also. P. oryzae mycelial growth was less affected by them. $H$. officinalis oil reduced germination of uredospores of Uromyces viciae-fabae and Botrytis fabae conidia but, its effects on pathogen infection were less clear-cut. Thus, its effects against apple powdery mildew and barley powdery mildew were variable although $0.05 \% \mathrm{H}$. officinalis oil reduced rust infection of broad bean when applied 1,2 or 3 days before, or 1 or 2 days after inoculation (Letessier et al., 2001).

The two essential oils from $H$. officinalis grown in two different localities near Urbino (Italy, Marche) and grown at 1000 $\mathrm{m}$ above sea level showed very high antifungal activity against different phytopathogenic fungi strains (Fraternale et al., 2004).

The fractionated and isolated growing hyphal Aspergillus fumigatus cell walls cultured in the absence or presence of essential oil from $H$. officinalis showed that the presence of essential oil caused a decrease in levels of uronic acid, proteins and neutral sugars, whereas phosphorus, lipids, and amino sugars levels were increased. Neutral sugars were mainly consisted of galactose, mannose, and glucose, while the amino sugars consisted of galactosamine and glucosamine as observed in HPLC analysis. H. officinalis oil presence induced marked changes in the content of galactosamine and galactose in the culture medium. $H$. officinalis oil also induced similar changes in the different fractions with a more distinct effect on the major components (Ghfir et al., 1997).

The biocidal (nematicidal, ixodicidal, phytotoxic and insecticidal) effects of industrial steam distilled essential oil from $H$. officinalis was effective and robustly active against $S$. littoralis (Ortiz de Elguea-Culebras et al., 2018).

\section{Antimicrobial activity}

The disc diffusion tests carried out on Gram+ve (Enterococcus spp. and Staphylococcus aureus) and Gram-ve bacteria (Pseudomonas spp., Proteus mirabilis, Escherichia coli, Klebsiella oxytoca, and two strains of Salmonella spp.) showed 
an antimicrobial activity insignificant for $H$. officinalis essential oil from Italy (Piedmont), but broader, and in a few cases more evident (E. coli and Enterococcus spp.) and for essential oil of var. decumbens (Jordan \& Fourr.). All yeasts (C. tropicalis, C. krusei and seven strains of Candida albicans) were robustly inhibited by both species. In liquid medium, the MIC of $H$. officinalis was between $0.6 \%$ and $1.2 \% \mathrm{v} / \mathrm{v}$ for yeasts and always $41.2 \% \mathrm{v} / \mathrm{v}$ for bacteria, while the MIC of var. decumbens was between $0.15 \%$ and $0.3 \% \mathrm{v} / \mathrm{v}$ for the yeasts, $0.3 \%$ and $1.2 \% \mathrm{v} / \mathrm{v}$ for the Gramve bacteria and $0.15 \%$ and $0.6 \% \mathrm{v} / \mathrm{v}$ for the Gram+ve bacteria. H. officinalis var. decumbens was bactericidal. 1,8-Cineole and linalool contributed to the greater antimicrobial activity of var. decumbens in comparison with $H$. officinalis, while limonene was responsible for the antimycotic action observed in both oils (Mazzanti et al., 1998a).

H. officinalis has moderate in vitro antimicrobial activity against Gram+ve and Gram-ve bacteria and antioxidant activity together with antifungal, antiviral and insecticidal activities. It has shown $\boldsymbol{\alpha}$-glucosidase inhibitory, antiplatelet and myorelaxant activities in vivo (Fathiazad et al., 2011).

The $5 \mu \mathrm{l}$ and $10 \mu \mathrm{l}$ of $H$. officinalis essential oil from Southeast Anatolian, Turkey exhibited significant antimicrobial activity against Staphylococcus pyogenes, Staphylococcus aureus, Escherichia coli and Candida albicans, but not against Pseudomonas aeroginosa in disc diffusion test (Kizil et al., 2010; Vlase et al., 2014).

The coriander and H. officinalis essential oils $(0.02 \%$ $\mathrm{v} / \mathrm{w}$ ) inhibited the growth of Enterobacteriaceae and the development of undesirable sensory changes in vacuum-packed beef meat stored at $6 \pm 1{ }^{\circ} \mathrm{C}$ and $0.5 \pm 0.5^{\circ} \mathrm{C}$ for 15 days. The effect on the total viable bacterial count of lactic acid bacteria and other groups of microorganisms was minor and similar for both oils. These additives did not significantly affect protein electropherograms, meat pigments, protease activity, $\mathrm{pH}$ levels and amino nitrogen levels indicating the limited effect of these oils in the concentrations applied on preserving vacuum-packed minced beef (Michalczyk et al., 2012).

The essential oil from $H$. officinalis L. ssp. angustifolius showed antimicrobial activity in vitro against a yeast $C$. albicans, fungi, and bacteria with minimum inhibitory concentration (MIC) of $15.62 \mu \mathrm{l} / \mathrm{ml}-250 \mu \mathrm{l} / \mathrm{ml}$ where the methanolic extract was inactive. The methanolic extract showed $\mathrm{IC}_{50}$ of $117.0 \mu \mathrm{g} / \mathrm{ml}$ in DPPH assay while $40 \%$ inhibition at $2 \mathrm{~g} / \mathrm{L}$ concentration in a linoleic acid system where essential oil was inactive (Özer et al., 2006).

\section{Antidiabetic activity}

Aqueous methanolic extract of dried $H$. officinalis leaves $(300 \mathrm{mg} / \mathrm{kg}$ and $100 \mathrm{mg} / \mathrm{kg}$ body weight, b.wt.) showed an $\alpha$-glucosidase inhibitory activity in mice (Miyazaki et al., 2003; Matsuura et al., 2004). It has antidiabetic activity but it is contraindicated in patients with liver affections (Akram et al., 2013).

\section{Antihemolytic activity}

H. officinalis extracts showed very good antihemolytic activity against $\mathrm{H}_{2} \mathrm{O}_{2}$-induced hemolysis in rat erythrocytes (48.51 $\pm 2.27 \mu \mathrm{g} / \mathrm{ml}$ for flowers, $19.47 \pm 0.73 \mu \mathrm{g} / \mathrm{ml}$ for leaves and $\mathrm{IC}_{50}$ $63.1 \pm 2.65 \mu \mathrm{g} / \mathrm{ml}$ for stems) (Alinezhad et al., 2013).

\section{Antiulcer activity}

Pre-treatment with $100 \mathrm{mg} / \mathrm{kg}$ and $125 \mathrm{mg} / \mathrm{kg} \mathrm{b.} \mathrm{wt.}$ of $H$. officinalis ethanolic extract to albino rats $1 \mathrm{~h}$ before the administration of ethanol showed a great antioxidant and antiulcer potential depicted by decreased nitric oxide level, decreased reactive oxygen species (ROS) generation, improved integrity of stomach and improved mucus secretion supporting its traditional use in folk medicine (Saini and Sharma, 2012).

The $H$. officinalis extract enriched in polyphenolic compounds (phenolic acids, tannins, and flavonoids) showed a significant inhibition (92.67\%) against urease obtained from jack bean and low inhibition (19.6\%) against $\alpha$-chymotrypsin which could be considered as a possible remedy in ulcer treatment (Paun et al., 2014).

\section{Antileishmaniasis activity}

Ointment-based $H$. officinalis extracts applied topically two times daily for 20 days effectively reduced the cutaneous ulcer size and burden of Leishmania parasite in the spleen as compared to glucantime in specific BALB/C mice (Akhlaghi et al., 2014).

\section{Mosquito larvicide activity}

H. officinalis essential oil showed lethal concentration $\left(\mathrm{LC}_{50}\right)$ values higher than $90 \mu \mathrm{l} / \mathrm{L}$ in acute toxicity study against binary mixtures of Culex quinquefasciatus vector, a vector of lymphatic filariasis, supporting it as eco-friendly, effective and cheap mosquito larvicides (Benelli et al., 2017).

\section{Airway remodeling inhibition}

The expression of both TIMP-1 and MMP-9 decreased after being treated with standard dexamethasone and Uygur herb $H$. officinalis accompanied by the relieved pathological changes including smooth muscle proliferation, mucus secretion and collagen deposition supporting its airway remodeling inhibition by correcting the imbalance of MMP-9/TIMP-1 ratio (Ma et al., 2014a).

\section{Antispasmodic activity}

Essential oil from $H$. officinalis var. decumbens and linalool non-competitively inhibited the barium chloride-induced and acetylcholine-induced contractions of isolated guinea pig ileum in a concentration-dependent manner $\left(\mathrm{IC}_{50}\right.$ values: $H$. officinalis var. decumbens $60 \mathrm{mg} / \mathrm{ml}$ and $37 \mathrm{mg} / \mathrm{ml}$; linalool 51 $\mathrm{mg} / \mathrm{ml}$ and $10 \mathrm{mg} / \mathrm{ml}$ ). 1,8-Cineole and limonene also showed only a weak spasmogen action (Mazzanti et al.,1998b).

\section{Anti-inflammatory activity}

The eosinophils ratio in bronchoalveolar lavage fluid and the levels of serum immunoglobulins $\operatorname{Ig} G$ and $\operatorname{Ig} E$ in the $H$. officinalis treatment group were decreased compared to ovalbumin and dexamethasone-treated group (chronic asthmatic) observed by enzyme-linked immunosorbent assay (ELISA). H. officinalis also affected the immune regulation (Ma et al., 2014b).

\section{Muscle relaxant activity}

The essential oil of $H$. officinalis inhibited the barium chloride $\left(\mathrm{BaCl}_{2}\right)$-induced and acetyl choline ( $\mathrm{ACh}$ )-induced 
muscle contractions in the isolated guinea-pig ileum. Essential oil also decreased the basal tone and reduced the amplitude of spontaneous movements in isolated rabbit jejunum ( $\mathrm{Lu}$ et al., 2002).

\section{Antiasthmatic activity}

Uygur herb $H$. officinalis could affect the levels of some cytokines (such as IL-17, IL-6, IL-4 and interferon (IFN)- $\gamma$ ) in asthmatic mice (Ma et al., 2014a).

\section{Anti-HIV activity}

Methanolic extracts, subsequent to ether, chloroform and chloroform-ethanol extractions of dried leaves of Hyssopus officinalis, showed very strong anti-HIV (Human Immunodeficiency Virus) activity as measured by inhibition of HIV reverse transcriptase, p17 and p24 antigen expression and syncytia formation probably due to caffeic acid and it may be useful in the treatment of patients with acquired immunodeficiency syndrome (AIDS) (Kreis et al., 1990).

A polysaccharide from $H$. officinalis aqueous extract showed anti-HIV activity against HIV-1 in HUT78 T cell line as demonstrated by the inhibition of syncytia formation and HIV-1 p24 antigen (Gollapudi et al., 1995).

A summary of different pharmacological activities of Hyssopus officinalis L. is shown in Table 1.

Table 1. Different pharmacological activities of Hyssopus officinalis L.

\begin{tabular}{|c|c|}
\hline Pharmacological activities & References \\
\hline Antioxidant activity & $\begin{array}{l}\text { Fernández-López et al., 2003; Wang and Yang, } \\
\text { 2010; Kizil et al., 2010; Fathiazad et al., 2011; } \\
\text { Zheljazkov et al., 2012; Alinezhad et al., 2013; } \\
\text { Hatipoglua et al., 2013; Vlase et al., } 2014\end{array}$ \\
\hline Anticonvulsant activity & Hold et al., 2002 \\
\hline Antifungal activity & $\begin{array}{l}\text { Ghfir et al., 1997; Letessier et al., 2001; } \\
\text { Fraternale et al., 2004; Ortiz de } \\
\text { Elguea-Culebras et al., } 2018\end{array}$ \\
\hline Antimicrobial activity & $\begin{array}{l}\text { Mazzanti et al., 1998a; Özer et al., 2006; } \\
\text { Kizil et al., 2010; Fathiazad et al., 2011; } \\
\text { Michalczyk et al., 2012; Vlase et al., } 2014\end{array}$ \\
\hline Antidiabetic activity & $\begin{array}{l}\text { Miyazaki et al., 2003; Matsuura et al., 2004; } \\
\text { Akram et al., } 2013\end{array}$ \\
\hline Antihemolytic activity & Alinezhad et al., 2013 \\
\hline Antiulcer activity & Saini and Sharma, 2012; Paun et al., 2014 \\
\hline Antileishmaniasis activity & Akhlaghi et al., 2014 \\
\hline Mosquito larvicide activity & Benelli et al., 2017 \\
\hline Airway remodeling inhibition & Ma et al., 2014a \\
\hline Antispasmodic activity & Mazzanti et al.,1998b \\
\hline Anti-inflammatory activity & Ma et al., 2014b \\
\hline Muscle relaxant activity & Lu et al., 2002 \\
\hline Antiastmatic activity & Ma et al., 2014b \\
\hline Anti-HIV activity & Kreis et al., 1990; Gollapudi et al., 1995 \\
\hline
\end{tabular}

\section{METABOLISM OF PRINCIPAL ACTIVE INGREDIENTS IN H. OFFICINALIS OIL}

The major metabolite of the principal active ingredients in H. officinalis oil i.e., cis-3-pinanone in each $\mathrm{P}_{450}$ system and in the brain of the ip treated mouse was 2-hydroxy-cis-3-pinanone, and two minor metabolites were hydroxypinanones other than 2-hydroxy-trans-3-pinanone and 4-S-hydroxy-cis-3-pinanone in GCMS analysis. The urine from oral cis-3-pinanone treatment examined on a qualitative basis contained conjugates of metabolites observed in the microsomal systems plus 2,10-dehydro-3pinanone. Trans-3-pinanone was metabolized more slowly than the $c i s$-isomer in each system to give hydroxy derivatives different than those derived from cis-3-pinanone (Hold et al., 2002).

A microsomal preparation from leaf epidermis oil glands of $H$. officinalis converts the parent olefin (-)- $\beta$-pinene to the allylic alcohol. $(+)$-trans-pinocarveol that presumably gives rise to (-)-pinocamphone and (-)-isopinocamphone by subsequent oxidation and two stereochemical alternatives for reduction of the conjugated double bond. The same preparation catalyzes the hydroxylation of $(-)$ - $\alpha$-pinene to $(-)$-myrtenol at a slower rate. The pinene hydroxylase from the oil glands of $H$. officinalis has characteristics of a distinct cytochrome P-450 species. Parent cyclic olefins were metabolized by a pathway involving allylic oxidation and conjugate reduction (Karp and Croteau, 1992).

\section{CONCLUSION}

Present review elaborated that the medicinal plant H. officinalis L. possesses numerous phytoconstituents such as quercetin-7-O- $\beta$-D-apiofuranosyl- $(1 \rightarrow 2)-\beta$-D-xylopyranoside and quercetin-7-O- $\beta$-D-apiofuranosyl- $(1 \rightarrow 2)-\beta$-D-xylopyranoside3'-O- $\beta$-D-glucopyranoside and also possesses various pharmacological or biological activities such as antioxidant, anticonvulsant, antifungal, antimicrobial, antihemolytic, antiulcer and antispasmodic activities. The plant $H$. officinalis L. is a quite significant medicinal plant possessing several phytoconstituents of pharmaceutical importance and which can be utilized for the amelioration and treatment of several diseases such as microbial infection, epilepsy, ulcer, and spasm. The present review compiled and summarized the significant published works on the medicinal plant $H$. officinalis L. traditionally used in several systems of medicine such as Unani and Ayurveda covering the phytochemistry, pharmacology and its traditional uses which can be further evaluated to achieve lead molecules in the search of novel herbal drugs.

\section{ACKNOWLEDGMENTS}

Authors are thankful to the Department of Pharmacy, Integral University Lucknow for their encouragement, motivation towards publication and research atmosphere during the recent literature search and future's planned research study (manuscript communication number provided by the University: IU/R\&D/2018-MCN000354).

\section{CONFLICT OF INTEREST}

The authors report no conflicts of interest.

\section{REFERENCES}

Akhlaghi L, Yeganeh M, Maleki F, Golestani M, Noori M, Ghelman M, Tabatabaie F. Antileishmanial activity of Hyssopus officinalis, Tussilage farfara, Carum copticum extracts in mice infected with Leishmania major. Int J Herb Med, 2014; 2:142-145.

Akram M. Diabetes mellitus type-II: treatment strategies and options: a review. J Diabetes Metab, 2013; 4:1-9. 
Alinezhad H, Azimi R, Zare R, Ebrahimzadeh MA, Eslami S, Nabavi SF, Nabavi SF, Antioxidant and antihemolytic activities of ethanolic extract of flowers, leaves, and stems of Hyssopus officinalis L. var. angustifolius. Int J Food Prop, 2013; 16:1169-1178.

Benelli G, Pavela R, Canale A, Cianfaglione K, Ciaschetti G, Conti F, Nicoletti M, Senthil-Nathan S, Mehlhorn H, Maggi F. Acute larvicidal toxicity of five essential oils (Pinus nigra, Hyssopus officinalis, Satureja montana, Aloysia citrodora and Pelargonium graveolens) against the filariasis vector Culex quinquefasciatus: synergistic and antagonistic effects. Parasitol Int, 2017; 66:166-171.

Fathiazad F, Mazandarani M, Sanaz Hamedeyazdan S. Phytochemical analysis and antioxidant activity of Hyssopus officinalis L. from Iran. Adv Pharm Bull, 2011;1: 63-67.

Fernández-López J, Sevilla L, Sayas-Barberá E, Navarro C, Marín F, Pérez-Alvarez JA. Evaluation of the antioxidant potential of Hyssop (Hyssopus officinalis L.) and Rosemary (Rosmarinus officinalis L.) extracts in cooked pork meat. J Food Sci, 2003; 68:660-664.

Fraternale D, Ricci D, Epifano F, Curini M. Composition and antifungal activity of two essential oils of Hyssop (Hyssopus officinalis L). J Essent Oil Res, 2004; 16:617-622.

Garg SN, Naqvi AA, Singh A, Ram G, Kumar S. Composition of essential oil from an annual crop of Hyssopus officinalis grown in Indian plains. Flavour Fragr J, 1999; 14:170-172.

Ghfir B, Fonvieille JL, Dargent R. Influence of essential oil of Hyssopus officinalis on the chemical composition of the walls of Aspergillus fumigatus (Fresenius). Mycopathologia, 1997; 138:7-12.

Gollapudi S, Sharma HA, Aggarwal S, Byers LD, Ensley HE, Gupta S. Isolation of a previously unidentified polysaccharide (MAR10) from Hyssop officinalis that exhibits strong activity against human immunodeficiency virus type 1. Biochem Biophys Res Commun, 1995; 210:145-151.

Hatipoglu G, Sokmen M, Bektas E, Daferera D, Sokmen A, Demir E, Sahin H. Automated and standard extraction of antioxidant phenolic compounds of Hyssopus officinalis L. ssp. angustifolius. Ind Crops Prod, 2013; 43:427-433.

Hold KM, Sirisoma NS, Sparks SE, Casida JE. Metabolism and mode of action of cis- and trans-3-pinanones (the active ingredients of hyssop oil). Xenobiotica, 2002; 32:251-265.

Karp F, Croteau R. 1992. Hydroxylation of (-)- $\beta$-pinene and (-)- $\boldsymbol{\alpha}$-pinene by a cytochrome P-450 system from Hyssop (Hyssopus Officinalis). In: Petroski RJ, McCormick SP, eds. Secondary-Metabolite Biosynthesis and Metabolism. Environ Sci Res. Springer: Boston, MA 44.

Kazazi H, Rezaei K, Ghotb-Sharif SJ, Emam-Djomeh Z, Yamini Y. Supercritical fluid extraction of flavors and fragrances from Hyssopus officinalis L. cultivated in Iran. Food Chem, 2007; 105:805-811.

Kerrola K, Galambosi B, Kallio H. Volatile components and odor intensity of four phenotypes of Hyssop (Hyssopus officinalis L.). J Agric Food Chem, 1994; 42:776-781.

Khazaiea HR, Nadjafib F, Bannayana M, Effect of irrigation frequency and planting density on herbage biomass and oil production of thyme (Thymus vulgaris) and hyssop (Hyssopus officinalis). Ind Crops Prod, 2008; 27:315-321.

Kizil S, Hasimi N, Tolan V, Kilinc E, Karatas H. Chemical composition, antimicrobial and antioxidant activities of Hyssop (Hyssopus officinalis) essential oil. Not. Bot. Hort. Agrobot Cluj, 2010; 38:99-103.

Kizil S, Toncer O, Ipek A, Arslan N, Saglam S, Khawar KM. Blooming stages of Turkish hyssop (Hyssopus officinalis L.) affect essential oil composition. Acta Agric Scand B Soil Plant Sci, 2008; 58:273-279.

Kreis W, Kaplan MH, Freeman J, Sun DK, Sarin PS. Inhibition of HIV replication by Hyssop officinalis extracts. Antivir Res, 1990; $14: 323-337$

Langa E, Cacho J, Palavra AMF, Burillo J, Mainar AM, Urieta JS. The evolution of hyssop oil composition in the supercritical extraction curve modelling of the oil extraction process. J Supercrit Fluids, 2009; 49:37-44.
Letessier MP, Svoboda KP, Walters DR. Antifungal activity of the essential oil of Hyssop (Hyssopus offcinalis). J Phytopathol, 2001; 149:673-678

$\mathrm{Lu} \mathrm{M}$, Battinelli L, Daniele C, Melchioni C, Salvatore G, Mazzanti G. Muscle relaxing activity of Hyssopus officinalis essential oil on isolated intestinal preparations. Planta Med, 2002; 68:213-216.

Ma X, Ma X, Ma Z, Sun Z, Yu W, Wang J, Li F, Ding J. The effects of Uygur herb Hyssopus officinalis L. on the process of airway remodeling in asthmatic mice. Evid-Based Complementary Altern Med, 2014a; 2014:1-7.

Ma X, Ma X, Ma Z, Wang J, Sun Z, Yu W, Li F, Ding J. Effect of Hyssopus officinalis L. on inhibiting airway inflammation and immune regulation in a chronic asthmatic mouse model. Exp Ther Med, 2014b; $8: 1371-1374$

Marin FR, Ortuño A, Benavente-Garcia O, Del-Rio JA. Distribution of flavone glycoside diosmin in Hyssopus officinalis plants: changes during growth. Planta Med, 1998; 64:181-182.

Matsuura H, Miyazaki H, Asakawa C, Amano M, Yoshihara T, Mizutani J. Isolation of $\boldsymbol{\alpha}$-glucosidase inhibitors from hyssop (Hyssopus officinalis). Phytochemistry, 2004; 65:91-97.

Mazzanti G, Battinelli L, Salvatore G. Antimicrobial properties of the linalool-rich essential oil of Hyssopus officinalis L. var decumbens (Lamiaceae). Flavour Fragr J, 1998a; 13:289-294.

Mazzanti G, Lu M, Salvatore G. Spasmolytic action of the essential oil from Hyssopus officinalis L. var. decumbens and its major components. Phytother Res, 1998b; 12:S92-S94.

Michalczyk M, Macura R, Tesarowicz I, Banaś J. Effect of adding essential oils of coriander (Coriandrum sativum L.) and hyssop (Hyssopus officinalis L.) on the shelf life of ground beef. Meat Sci, 2012; 90:842-850.

Mijani S, Nasrabadi ES, Zarghani H, Abadi MG. Seed germination and early growth responses of Hyssop, sweet basil, and oregano to temperature levels. Not Sci Biol, 2013; 5:462-467.

Miyazaki H, Matsuura H, Yanagiya C, Mizutani J, Tsuji M, Ishihara C. Inhibitory effects of hyssop (Hyssopus officinalis) extracts on intestinal alpha-glucosidase activity and postprandial hyperglycemia. J Nutr Sci Vitaminol, 2003; 49:346-349.

Ortiz de Elguea-Culebras G, Sánchez-Vioque R, Berruga MI, Herraiz-Peñalver D, González-Coloma A, Andrés MF, Santana-Méridas O. Biocidal potential and chemical composition of industrial essential oils from Hyssopus officinalis, Lavandula x intermedia var. super, and Santolina chamaecyparissus. Chem Biodivers, 2018; 15:e1700313.

Özer H, Sökmen M, Güllüce M, Adigüzel A, Kilic H, Şahin F, Bariş Ö. In vitro antimicrobial and antioxidant activities of the essential oils and methanol extracts of Hyssopus officinalis L. ssp. angustifolius. Ital J Food Sci, 2006; 18:73-83.

Pandey V, Verma RS, Chauhan A, Tiwari R. Compositional variation in the leaf, flower, and stem essential oils of Hyssop (Hyssopus officinalis L.) from western-Himalaya. J Herb Med, 2014; 4:89-95.

Paun G,Litescu SC, Neagu E, TacheA,Lucian-Radu G.Evaluation of Geranium spp., Helleborus spp. and Hyssopus spp. polyphenolic extracts inhibitory activity against urease and $\alpha$-chymotrypsin. J Enzyme Inhib Med Chem, 2014; 29:28-34.

Piccaglia R, Pace L, Tammaro F. Characterization of essential oils from three Italian ecotypes of Hyssop [Hyssopus officinalis L. subsp. aristatus (Godron) Briq.]. J Essent Oil Res 1999; 11:693-699.

Saini A, Sharma R. To explore the ulcer protective and antioxidant potential of Hyssopus officinalis in ethanol-induced gastric ulcers in rats. Br J Pharm Res, 2012; 2:197-214.

Schulz G, Stahl-Biskup E. Essential oils and glycosidic bound volatiles from leaves, stems, flowers, and roots of Hyssopus oficinalis L. (Lamiaceae). Flavour Fragr J, 1991; 6:69-73.

Tabrizi L, Koocheki A, Ghorbani R. 2008. Effect of biofertilizers on agronomic criteria of hyssop (Hyssopus officinalis). 2nd Conference of the International Society of Organic Agriculture Research ISOFAR, Modena, Italy. 
Thome OW. Flora von Deutschland. Österreich und der Schweiz 1885 , Gera, Germany.

Tsankova ET, Konaktchiev AN, Genova EM. The chemical composition of the essential oils of two Hyssopus officinalis Taxa. J Essent Oil Res, 1993; 5:609-611.

Vallejo MCG, Herraiz JG, Pérez-Alonso MJ, VelascoNegueruela A. Volatile oil of Hyssopus officinalis L. from Spain. J Essent Oil Res, 1995; 7:567-568.

Vlase L, Benedec D, Hanganu D, Damian G, Csillag I, Sevastre B, Mot AC, Silaghi-Dumitrescu R, Tilea I. Evaluation of antioxidant and antimicrobial activities and phenolic profile for Hyssopus officinalis, Ocimum basilicum and Teucrium chamaedrys. Molecules, 2014; 19:54905507.

Wang N, Yang XW. Two new flavonoid glycosides from the whole herbs of Hyssopus officinalis. J Asian Nat Prod Res, 2010; 12:10441050 .
Wesolowska A, Jadczak D, Grzeszczuk M. Essential oil composition of hyssop (Hyssopus officinalis L.) cultivated in north-western Poland. Herba Pol, 2010; 56:57-65.

Zawislak G. Hyssop herb yield and quality depending on harvest term and plant spacing. Acta Sci Pol-Hortorum Cultus, 2011; 10:331-342.

Zheljazkov VD, Astatkie T, Hristov AN. Lavender and hyssop productivity, oil content, and bioactivity as a function of harvest time and drying. Ind Crops Prod, 2012; 36:222-228.

How to cite this article:

Tahir M, Khushtar M, Fahad M, Rahman A. Phytochemistry and pharmacological profile of traditionally used medicinal plant Hyssop (Hyssopus officinalis L.). J App Pharm Sci, 2018; 8(07): 132-140. 